\title{
Diversifikasi Pangan Olahan Jagung Manis Sebagai Upaya Pengembangan Agroindustri di Desa Soropaten
}

\author{
Lak Lak Nazhat El Hasanah $^{* 1)}$, Dessy Isfianadewi ${ }^{2)}$ \\ ${ }^{1)}$ Prodi Ilmu Ekonomi Fakultas Ekonomi Universitas Islam Indonesia, \\ *Email : lak_lak@uii.ac.id \\ ${ }^{2)}$ Prodi Manajemen Fakultas Ekonomi Universitas Islam Indonesia, \\ Email : dessy.isfianadewi@uii.ac.id
}

\begin{abstract}
Abstrak
Kegiatan pengabdian yang dilakukan ini bertujuan meningkatkan produktivitas masyarakat melalui pengembangan agroindustri yang dimiliki desa dengan mengenalkan dan mempraktikan cara mengolahnya sehingga menjadi produk yang berkualitas sehingga bisa meningkatkan pendapatan masyarakat desa tersebut. Jagung merupakan salah satu jenis agroindustri yang menjadi potensi unggulan Desa Soropaten, Karanganom, Klaten. Jagung merupakan tanaman dengan kandungan gizi yang tinggi dan memiliki nilai ekonomis, dengan demikian jagung bisa menjadi salah satu agroindustri yang memiliki nilai tambah apabila didiversifikasi menjadi beberapa bentuk olahan pangan. Metode yang digunakan berupa penyuluhan, praktek dan pendampingan bagaimana mengolah jagung menjadi olahan pangan seperti keripik jagung, marning aneka rasa, dodol jagung maupun es mambo atau es lilin, kemudian pengemasan, mengurus perijinan dan sampai pada pemasarannya. Adanya kegiatan ini warga Desa Soropaten dapat mengolah potensi unggulannya yaitu jagung menjadi aneka macam produk dan menjadikannya sebagai usaha dalam meningkatkan pendapatan dan kesejahteraan masyarakat yang berkelanjutan.
\end{abstract}

Keywords: Agroindustri, Diversifikasi, Jagung, Kesejaheraan yang Berkelanjutan

\section{PENDAHULUAN}

Agroindustri merupakan suatu kegiatan industri yang memiliki keunggulan komparatif berupa penggunaan bahan baku yang berasal dari sumberdaya alam yang tersedia di dalam negeri [1]. Agroindustri merupakan bagian dari sistem besar agribisnis, yang memiliki aktivitas pengolahan bahan baku pertanian dengan menggunakan teknologi, untuk menghasilkan produk baru. Sebut saja produk buah dan sayuran dalam kemasan yang menjadi potensi di banyak wilayah di Indonesia, dengan kata lain adalah industri pengolahan hasil pertanian. Agroindustri merupakan bentuk industri yang sesuai untuk di kembangkan di pedesaan, dengan tenaga dan bahan baku juga dari lokasi pedesaan [2]. Keberadaan agroindustri diharapkan mampu menciptakan pasar bagi hasil-hasil pertanian melalui produk olahannya [3]. Agar agroindustri dapat berperan sebagai penggerak utama perekonomian daerah, industrialisasi pedesaan harus memenuhi persyaratan sebagai berikut yaitu: berlokasi di pedesaan, terintegrasi vertikal ke bawah, mempunyai kaitan input-output yang besar dengan industri lainnya, dimiliki oleh penduduk desa, padat tenaga kerja, tenaga kerja berasal dari desa, bahan baku merupakan produksi desa, dan produk yang dihasilkan terutama dikonsumsi pula oleh penduduk desa.

Jagung merupakan salah satu produk pertanian yang bisa dikembangkan sebagai produk agroindustri, karena daya saing yang dimiliki komoditas jagung di skala nasional cukup baik. Hal ini ditunjukkan oleh indikator komparatif (DRCR) dan keunggulan kompetitif (PCR) yang kurang dari satu [4]. Selain itu, jagung merupakan komoditas yang mempunyai kandungan gizi yang cukup tinggi sehingga nilai jual jagung juga cukup meningkatkan nilai ekonomis komoditas tersebut. Kandungan karotenoid pada jagung berkisar anatra 6,4-11,3 $\mu \mathrm{g} / \mathrm{g}$ hal inilah yang menyebabkan warna kuning pada jagung. Sekitar 22 persen diantaranya adalah $\beta$ karoten dan 51 persen xantofil. Diketahui bahwa $\beta$ karoten merupakan senyawa yang memiliki aktivitas antioksidan dan provitamin A [5]. Jagung memiliki peran yang strategis dalam perekonomian nasional di Indonesia. Hal ini mengingat fungsinya yang beraneka ragam baik sumber pangan, pakan, serta bahan baku industri. Di Indonesia, pemanfaatan jagung $60 \%$ digunakan sebagai bahan baku industri diantaranya $57 \%$ untuk pakan ternak. Selain sebagai sumber karbohidrat kompleks, jagung mengandung nutrisi yang sangat bermanfaat untuk kesehatan tubuh diantaranya vitamin $\mathrm{B}$ dan vitamin $\mathrm{C}$, karoten, 
kalium, zat besi, magnesium, forfor, omega 6, dan lemak tak jenuh yang dapat menurunkan kolesterol (Arma, Fermin, \& Sabaruddin, 2013); (Mahdiannoor, 2014); (Saputra, 2015)

Tabel 1. Komposisi kimia jagung berdasarkan bobot kering.

\begin{tabular}{|c|c|c|c|}
\hline $\begin{array}{r}\text { Komponen Biji } \\
\text { utuh }\end{array}$ & Endosperma & Lemba & $\begin{array}{r}\text { Kulit Tip } \\
\text { ari cap }\end{array}$ \\
\hline Protein (\%) 3,7 & 8,0 & 18,4 & $3,7 \quad 9,1$ \\
\hline Lemak (\%) 1,0 & 0,8 & 33,2 & $1,0 \quad 3,8$ \\
\hline $\begin{array}{l}\text { Serat kasar } 86,7 \\
(\%)\end{array}$ & 2,7 & 8,8 & $86,7-$ \\
\hline $\mathrm{Abu}(\%)$ & 0,3 & 10,5 & $0,8 \quad 1,6$ \\
\hline Pati (\%) & 87,6 & 8,3 & $7,3 \quad 5,3$ \\
\hline Gula (\%) & 0,62 & 10,8 & $0,341,6$ \\
\hline
\end{tabular}

Sumber : Sunarni dan Yasin, 2011.

Desa Soropaten merupakan salah satu desa di Jawa Tengah yang terletak di Kecamatan Karanganom Kabupaten Klaten. Mayoritas masyarakat Soropaten memiliki perkebunan jagung yang cukup luas. Luas lahan tanaman jagung di Soropaten memiliki luas yang paling tingi diantara desa-desa lain di wilayah Kecamatan Karanganom yaitu $98 \mathrm{Ha}$ [9].Luas lahan jagung di Kecamatan Karanganom. bisa dilihat pada tabel 2:

Tabel 2. Luas lahan jagung Desa-Desa di Kecamatan Karanganom

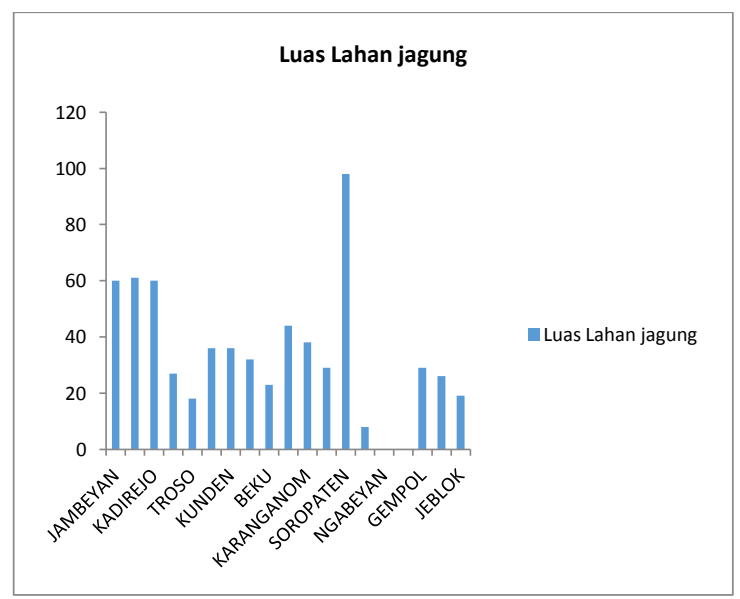

Sumber: BPS, 2018

Tabel 2 menunjukkan luas lahan jagung di desa-desa yang berada di Kecamatan Karanganom. Luas lahan jagung terendah ada di daerah Ngabeyan sedangkan yang tertinggi di Desa Soropaten. Tingginya panen jagung yang dimiliki masyarakat desa Soropaten menggerakan warga khususnya ibuibu desa Soropaten untuk memberikan nilai tambah pada tanaman tersebut sehingga mempunyai nilai jual tinggi dibanding hanya dijual tanpa diolah.
Selain itu, adanya kandungan gizi yang cukup tinggi pada komoditi jagung ini menjadi suatu ketertarikan tersendiri bagi warga untuk melakukan diversifikasi produk jagung, seperti yang telah dilakukan oleh [10] untuk KWT Enggal Sukses dan KWT Mekar Sari di Kecamatan Kuthasari, Purbalingga yang mengeringkan jagung menjadi tepung sehingga bisa diolah menjadi beraneka macam produk lainnya. Optimalisasi potensi jagung melalui usaha olahan jagung diharapkan dapat menjadi usaha rumahan berbasis agroindustri bagi warga Desa Soropaten sehingga dapat meningkatkan pendapatan dan kesejahteraan keluarganya, hal ini sesuai dengan penelitian yang telah dilakukan oleh (Suryono, 2011) dengan hasil bahwa pemanfaatan tersebut? menambah kompetensi dari warga masyarakat untuk mendiversifikasi tanaman menjadi sesuatu yang bernilai tambah. Pengembangan potensi lokal melalui pemberdayaan tersebut dilakukan dengan penerapan teknologi sederhana yang mudah diaplikasikan oleh masyarakat, namun tetap dapat meningkatkan nilai guna potensi tersebut. Teknologi sederhana yang dilatihkan dan diterapkan adalah pengolahan tanaman lokal menjadi beberapa produk olahan jadi baik makanan maupun minuman serta pemasaran dengan peningkatan kualitas baik varian maupun pengemasannya.

Diversifikasi merupakan suatu konsep pengembangan produktivitas suatu barang dengan memberikan nilai tambah terhadap suatu produk sehingga dapat menaikkan penetrasi pasar [11]. Semakin beragam produk yang ditawarkan kepada konsumen, semakin besar ketertarikan konsumen untuk membeli produk yang ditawarkan [12]

Salah satu diversifikasi pangan dari jagung yang sudah ada di desa Soropaten adalah marning akan tetapi masih banyak permasalah dalam pengembangannya. Adapun permasalah yang ada di Desa Soropaten terkait pengembangan agroindustri berbasis jagung adalah:

- Pengolahan jagung yang terbatas seperti marning dari melimpahnya produksi jagung di Desa Soropaten

- Belum adanya usaha lain dari olahan jagung dalam rangka diversifikasi pangan untuk memberikan nilai tambah produk sehingga mempunyai nilai ekonomi yang lebih untuk meningkatkan kesejahteraan atau belum ada suatu program yang dapat memberdayakan warga khususnya ibu-ibu di desa ini secara aktif dari potensi unggulan desa.

- Kemasan dan pelabelan produk yang masih sederhana sehingga kurang menarik bagi konsumen karena kurangnya pengetahuan tentang pemasaran suatu produk.

- Belum adanya ijin usaha dari olahan jagung yang sudah ada. 


\section{TARGET DAN LUARAN}

Target dan luaran dalam program ini adalah mengoptimalkan produksi jagung di Desa Soropaten melalui peningkatan pengetahuan dan ketrampilan mengolah jagung menjadi aneka olahan pangan. Selain itu, adanya peningkatan pemasaran dari produk yang dihasilkan warga masyarakat desa Soropaten melalui pengemasan dan pelabelan produk yang baik sehingga mempunyai nilai ekonomi yang lebih. Terciptanya usaha rumah tangga berbasis olahan jagung sebagai bentuk pengembangan agroindustri di Desa Soropaten yang nantinya akan terintegrasi dengan Dadan Usaha Milik Desa Soropaten dalam pengembangan usaha tersebut.

\section{METODE PELAKSANAAN}

Pengembangan agroindustri yang dilakukan dalam kegiatan iptek bagi masyarakat dengan mendiversifikasi produk unggulan desa berbasis pertanian yaitu jagung. Adapun metode yang dilakukan dalam kegiatan pelatihan dan pendampingan desa mitra adalah :

1. Pelatihan dilakukan dengan metode ceramah dan demonstrasi (praktik). Metode ceramah dinilai lebih efektif untuk memberikan pengetahuan dasar mengenai diversifikasi pangan untuk memberikan nilai tambah pada suatu produk, mulai dari cara pembuatan (produksi) meliputi bahan yang disiapkan, pengolahan, pemasaran produk yang efektif dan langkah pembuatan ijin usaha rumah tangga.

Selain metode ceramah juga dilakukan metode demonstrasi (praktik) langkah-langkah pembuatan produk dengan bahan baku dari jagung. Hal ini bertujuan untuk mendemonstrasikan berbagai kegiatan yang dilakukan antara lain aplikasi diversifikasi produk keripik jagung maupun es mambo atau es lilin, variasi pengemasan produk jagung.

2. Metode pendampingan: metode ini dilakukan dalam rangka pengembangan agroindustri di Desa Soropaten. Setelah metode-metode diatas disampaikan dan mitra (ibu-ibu rumah tangga Desa Soropaten) memahami materi yang diberikan selanjutnya dilakukan pendampingan yang berkelanjutan sampai pada proses pendampingan dalam perijinan usaha rumah tangga. Pendampingan ini diharapkan dapat merubah sikap dan kesadaran dalam peningkatan ketrampilan untuk meningkatkan kesejahteraan melaui pemanfaatan potensi yang ada di desa.

Kegiatan ini melibatkan dua mahasiswa dari Prodi Ilmu Ekonomi dan Prodi Manajemen yang berperan sebagai pendamping tutor dalam kegiatan ini.

\section{HASIL DAN PEMBAHASAN}

Langkah awal yang dilakukan dalam kegiatan pengembangan masyarakat melalui potensi desa adalah observasi dan persiapan alat. Observasi dilakukan dalam upaya mengidentifikasi potensi yang ada di desa Soropaten dan melakukan atau mencari permasalahan yang ada terkait hasil identifikasi. Penggalian potensi dilakukan dengan wawancara dengan tokoh dan warga masyarakat. Berdasarkan wawancara dan data yang diperoleh dihasilkan bahwa jagung merupakan potensi pertanian yang menjadi unggulan di Desa Soropaten, warga juga mengungkapkan adanya keterbatasan pengetahuan dalam optimalisasi pemanfaat jagung (diversifikasi pangan) dalam meningkatkan pendapatan. Selama ini salah satu warga sudah melakukan diversifikasi jagung menjadi Marning dan keripik akan tetapi pemasaran belum maksimal.

Langkah selanjutnya adalah melakukan kegiatan dalam rangka penyelesaian masalah yang ditemukan yaitu peningkatan pengetahuan dan ketrampilan warga Desa Soropaten khususnya ibu-ibu rumah tangga dalam memproduksi pengolahan hasil jagung dan pemanfaatannya melalui penyuluhan dan pelatihan. Penyuluhan dilakukan dengan metode ceramah tentang manfaat jagung serta pemasaran produk jagung dengan nilai ekonomi yang lebih tinggi.

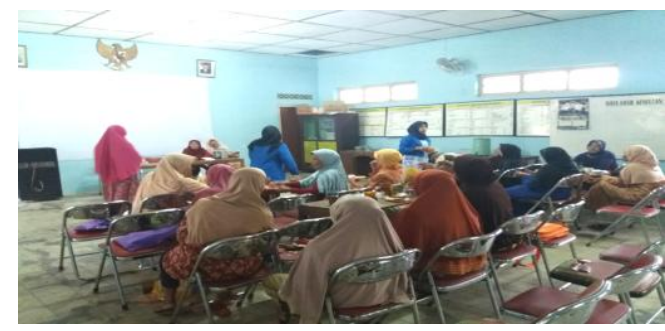

Gambar 1. Sosialisasi dan penyuluhan pemanfaatan dan pemasaran jagung

Adapun pelatihan dilakukan sebagai bentuk implementasi pengolahan jagung (diversifikasi pangan).

- Pelatihan pembuatan keripik dari jagung

Olahan keripik merupakan salah satu produk pangan yang banyak digemari oleh semua kalangan. Keripik ialah salah satu makanan ringan (snack food) yang tergolong jenis makanan cracker. Produk ini banyak disukai karena rasanya enak, renyah dan tahan lama, praktis mudah dibawa dan disimpan [13]. Adapun langkah-langkah pembuatannya adalah

1) Penyiapan alat dan bahan

Bahan yang digunakan dalam pembuatan keripik jagung adalah telur, bawang putih, garam, kapur, tepung terigu, dan minyak goreng. Telur digunakan agar keripik jagung yang dihasilkan 
menjadi mengembang ketika digoreng. Bawang putih dan garam digunakan untuk memperbaiki rasa pada keripik jagung. Tepung terigu dan kapur untuk menghasilkan keripik jagung yang renyah.

- Paktik olahan keripik jagung

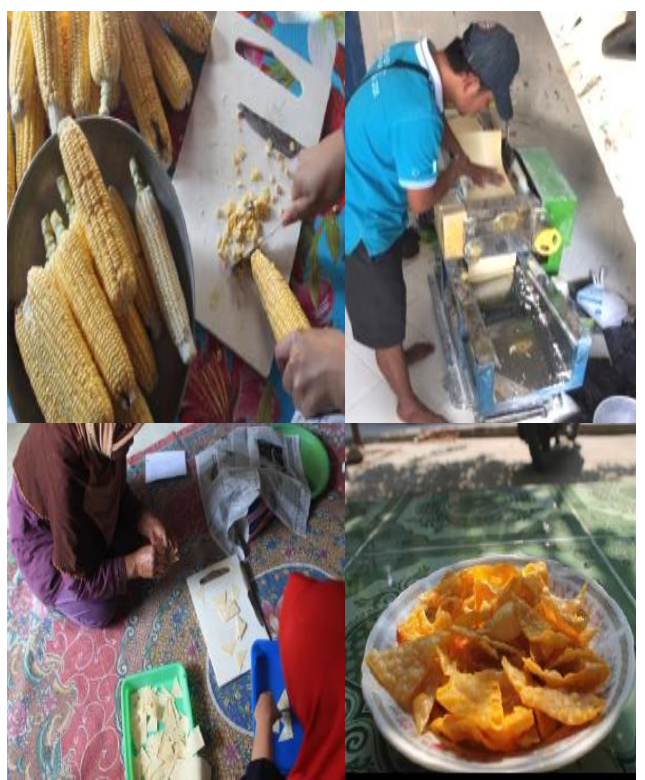

Gambar 2. Praktik Pembuatan Keripik

Tahapan diversifikasi produk pangan pertanian (agroindustri) menjadi makanan kripik dapat digambarkan sebagai berikut:

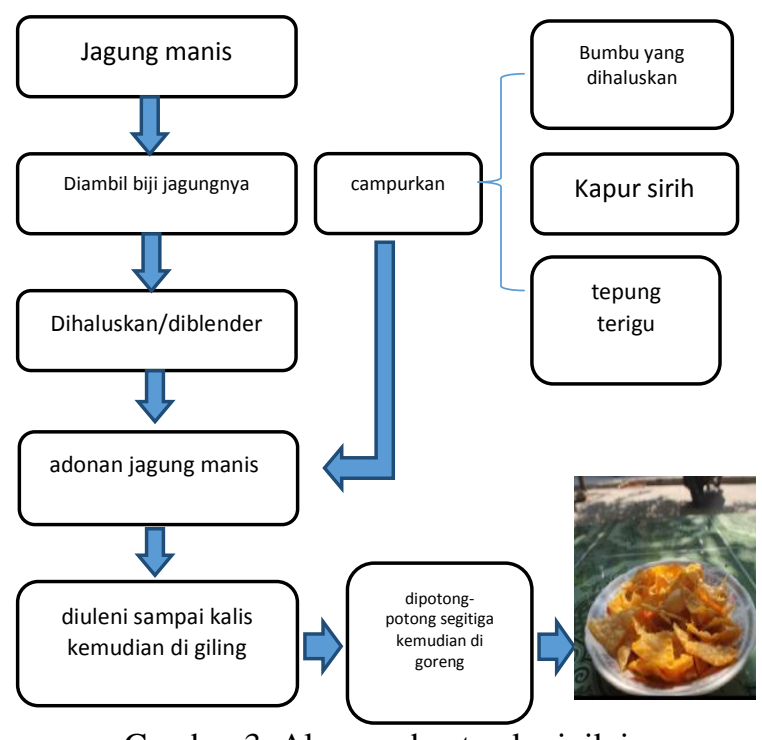

Gambar 3. Alur pembuatan keripik jagung

Diversifikasi pangan olahan jagung manis bisa juga dibuat untuk produk minuman yaitu pembuatan es mambo atau es lilin. Ide ini muncul dari warga karena es mambo atau es lilin atau es mambo merupakan komoditas minuman yang menarik bagi anak-anak. Adanya kandngan gizi yang cukup tinggi sehingga diharapkan akan menjadi asupan bagi anak-anak tersebut. Langkah-langkah pembuatan es mambo atau es lilin dengan bahan jagung manis. Bahan-bahan yang digunakan antara lain 3 bonggol jagung manis (sisir), 2lembar daun pandan , $600 \mathrm{ml}$ susu cair (1 sachet susu kental manis), $4 \mathrm{sdm}$ maizena (larutkan dengan sedikit, $500 \mathrm{ml}$ santan dari $\%$ butir kelapa (4 gelas air/aslinya $2 \mathrm{sdm}$ ) santan), 4 tetes pewarna kuning tua , $8 \mathrm{sdm}$ gula pasir (1 gelas gula pasir), 1/2 sdt garam , $1 / 4$ sdt vanili, plastik es lilin dan karet gelang. Alur pembuatan es mambo atau es lilin sebagai berikut :

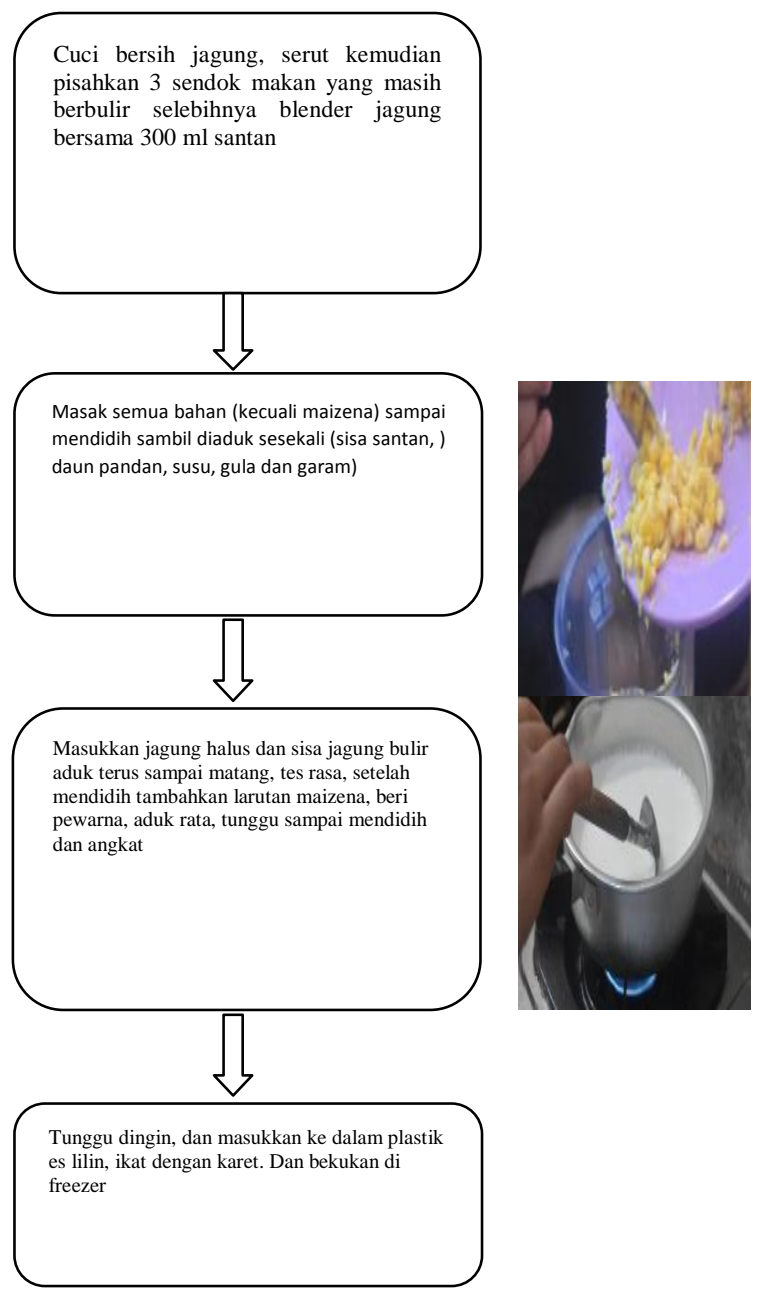

Gambar 4. Alur pembuatan es mambo atau es lilin

Diversifikasi produk pangan ini diharapkan dapat menarik konsumen sehingga dapat menambah pendapatan dari petani jagung tersebut. Beberapa penelitian menunjukkan bahwa strategi diversifikasi produk mempunyai dampak meningkatkan jumlah penjualan, dapat menjaga mutu produk dan produk dapat tahan lebih lama, sedangkan kelemahan dari implementasi strategi ini adalah harga dan 
ketersediaan alat produksi serta ketersediaan lahan produksi. Di sisi lain, produk yang baru tidak mempengaruhi tingkat penjualan produk yang lama. [12].

Penelitian lain yang dilakukan [14] tentang pengembangan desa wisata rumah dome berbasis agroindustri pangan lokal dengan kajian diversifikasi ketela pohon dimana mitra pengabdian adalah ibuibu PKK di rumah dome. Dengan metode pelatihan pengolahan ketela pohon menjadi keripik singkong berbagai rasa, keripik belut daun singkong, membuat brownies berbahan tepung ketela, mengemas produk dengan brand Rumah Dome dan memberikan pelatihan pembukuan sederhana. Hal ini dilakukan untuk meningkatkan pendapatan masyarakat.

Praktik selanjutnya adalah pemasaran produk. Produk yang sudah jadi kemudian di pack, pelatihan ini juga memberikan pengetahuan pemasaran produk mulai dati pack sampai ke penjualan produk dengan berbagai media. Produk desa yang sudah di packaging adalah keripik dan marning. Adapun untuk es mambo packaing masih sederhana. Selanjtnya melakukan pendaftaran produk untuk mendapatkan perijinan usasa rumah tangga (PIRT) seabagai bentuk pengembangan agroindustri di Desa Soropaten.

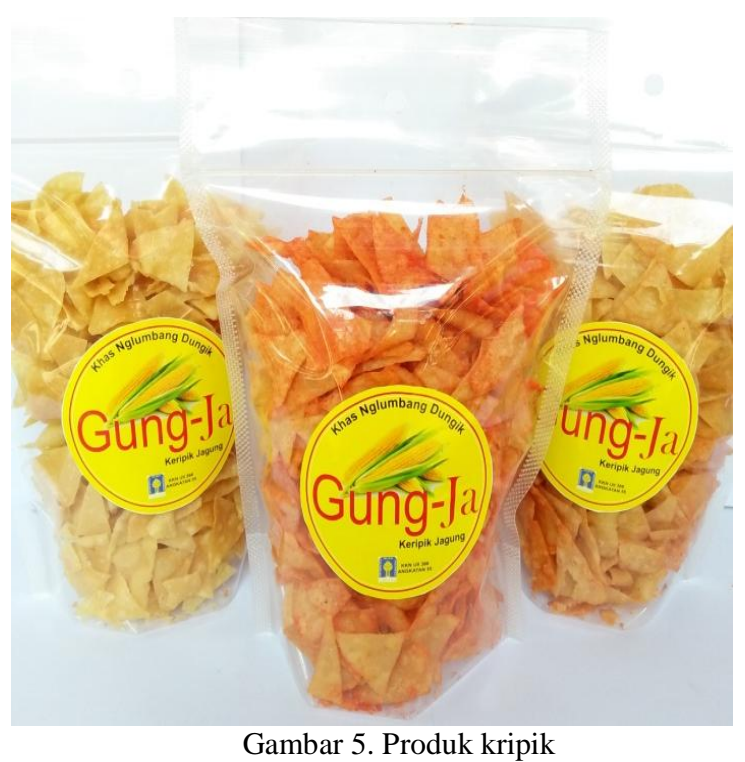

V. SIMPULAN

Program kegiatan pengembangan agroindustri di Desa Soropaten dilakukan dengan strastegi diversifikasi produk pangan olahan jagung manis menjadi keripik dan es mambo. Tingkat partisipasi yang tinggi dari mitra program pengabdian kepada masyarakat memberikan dampak positif bagi pelaksanaan program, terlihat dari pelatihan dan pendampingan program pengembangan agroindustri melalui diversifikasi pangan olahan jagung manis dan manajemen produksi, dapat berjalan dengan baik. Termasuk marketing pogramme terkait jenis produk yang ditawarkan di pasar belum disepakati oleh kelompok mengenai varian produk dari olahan berbasis industri rumah tangga yang akan dikelola dan dipasarkan.

\section{UCAPAN TERIMA KASIH}

Kelancaran kegiatan tidak lepas dari adanya kerjsama dari berbagai pihak diantara Universitas Islam Indonesia selaku pemberi dana, Mahasiswa dan Warga masyarakat Desa Soropaten.

\section{DAFTAR PUSTAKA}

[1] Disperindag., 2004. Program dan Strategi Pembangunan Industri Kimia, Agro dan Hasil Hutan. Jakarta: Direktorat Jenderal Industri Kimia, Agro dan Hasil Hutan (IKAH) 2000-2004.

[2] A. Suharjo.,1990. Konsep dan Ruang Lingkup Agroindustri," Bogor.

[3] P. Simatupang and A. Purwanto.,1990. Pengembangan Agroindustri Sebagai Penggerak Pembangunan Desa. Prosiding Agroindustri Faktor Penunjang Pembangunan Pertanian di Indonesia. Bogor: Pusat Penelitian Sosial Ekonomi Pertanian.

[4] A. Agustian.,2014. Daya saing komoditas padi, jagung, dan kedelai dalam konteks pencapaian swasembada pangan,Pusat Sosial Ekonomi dan Kebijakan Pertanian. [Online]. Available: http://pse.litbang.pertanian.go.id/ind/pdffiles/PB_ ANJAK_ADG_2014.pdf. [Accessed: 05-Jan2017].

[5] N. Aini., 2013. Teknologi Fermentasi pada Tepung Jagung. Yogyakarta (ID): Graha Ilmu.

[6] M. J. Arma, U. Fermin, and L. Sabaruddin., 2013. Pertumbuhan dan produksi jagung (Zea mays $L$.) dan kacang tanah (Arachis hypogaea L) melalui pemberian nutrisi organik dan waktu tanam dalam sistem tumpangsari, Jurnal Agroteknos,(3) (1) pp. 1-7.

[7] M. Mahdiannoor., 2014. Pertumbuhan Dan Hasil Tanaman Jagung Manis (Zea mays L. Var. Saccharata) Dengan Pemberian Pupuk Hayati Pada Lahan Rawa Lebak, Jurnal Ilmu Pertanian (39)(1), pp. 105-113.

[8] M. E. Saputra., 2015. Cara Pengolahan Jagung Manis Menjadi Berbagai Jenis Makanan, J. Ecopedon, (3) (1), pp. 107-111.

[9] BPS, 2018. Karanganom Dalam Angka. Klaten: BPS.

[10] K. Kutasari, N. Aini, and B. Sustriawan., 2018. IPTEK Bagi Masyarakat Perbaikan Teknologi Pengolahan Jagung bagi Kelompok Wanita Tani di, J-DINAMIKA,(3) (2), pp. 153-158.

[11] Y. E. Wijaya and O. Karneli., 2017. Pengaruh Diversifikasi Produk dan Harga terhadap kepuasan Pelanggan (Studi pada pelanggan Kenctuky Fried Chiken (KFC) Metropolitan City Pekanbaru," JOM FISISP, (4) (2), pp. 1-15.

[12] L. Hermawan., 2015. Strategi Diversifikasi Produk Pangan Olahan Tahu Khas Kediri," 
Jurnal Pengabdian Masyarakat J-DINAMIKA, Vol. 4, No. 1, Juni 2019,

P-ISSN : 2503-1031, E-ISSN: 2503-1112

Jurnal JIBEKA, (9) (2), pp. 26-32,.

[13] Lestari., 2015.Keripik kangkung rasa paru sebagai produk olahan guna meningkatkan nilai tambah, Seminar nasional,.

[14] S. W. Ani, M. T. Sundari, and E. Antriyandarti., 2013. Pengembangan Desa Wisata Rumah Dome Berbasis Agroindustri Pangan Lokal ( Kajian Diversifikasi Ketela Pohon di Desa Wisata Rumah Dome Prambanan )," Jurnal Agriekonomika, (2) (1), pp. 117-122. 